\title{
Efek Kepemilikan Institusional, Kinerja Perusahaan, Kualitas Audit terhadap Luas Pengungkapan CSR Perusahaan Pertambangan
}

\author{
Bagus Setyawan \\ e-mail : bagusabimtd@gmail.com \\ Gaguk Apriyanto \\ Achmad Firdiansjah \\ (Fakultas Ekonomi dan Bisnis, Universitas Merdeka Malang, Indonesia)
}

\begin{abstract}
ABSTRAK
Penelitian ini dilakukan dengan pengambilan data di Bursa Efek Indonesia (BEI) melalui situs web $\underline{w w w . i d x . c o . i d}$ dan Indonesian Capital Market Library (ICAMEL) melalui situs www.icamel.id. Sumber data penelitian ini adalah data sekunder yang diperoleh secara historis dari laporan tahunan, laporan keuangan, dan laporan keberlanjutan yang disajikan perusahaan pada tahun 2017-2018 yang telah go public dan terdaftar di Bursa Efek Indonesia. Dalam penelitian ini sampel yang diambil sesuai dengan kriteria yang digunakan dalam purposive sampling yang terdaftar selama tahun yang diteliti. Berdasarkan hasil yang didapatkan dengan menggunakan analisis kuantitatif, maka Hasil statistik deskriptif menunjukkan bahwa nilai rata-rata tata kepemilikan instistusional sebesar 55,92\%. Hal ini menunjukkan bahwa kepemilikan instisuional sudah cukup efektif dalam memonitor aktivitas manajemen. Kinerja perusahaan yang diproksikan dengan ROA, memiliki rata-rata sebesar 5,91\%. Hal ini menunjukkan bahwa perusahaan mampu menghasilkan keuntungan pada pada tahun 2017 dan 2018. Kualitas audit memiliki rata-rata sebesar 0,25, hal ini menunjukkan bahwa sebagian besar perusahaan diaudit bukan dari KAP Big 4. Pengungkapan (corporate social resposibility) CSR sebesar 71,35\%, hal ini menunjukkan bahwa perusahaan mampu mengeluarkan biaya untuk kegiatan pembangunan ekonomi, sosial dan lingkungan.
\end{abstract}

Kata Kunci : Kepemilikan Institusional, Kinerja Perusahaan, Luas Pengungkapan CSR, Kualitas Audit

\begin{abstract}
This type of research is causal associative research. This research examines the causal relationship. This research is included in quantitative research because it refers to the calculation in the form of numbers. The data source of this research is secondary data obtained historically from annual reports, financial reports, and sustainability reports presented by the company in 2017-2018 that have gone public and are listed on the Indonesia Stock Exchange. In this study, the samples taken were by the criteria used in the purposive sampling that were registered during the year under study. Based on the results obtained using quantitative analysis, the descriptive statistical results show that the average value of institutional ownership is $55.92 \%$. This shows that institutional ownership has been quite effective in monitoring management activities. Company performance which is proxied by ROA has an average of $5.91 \%$. This shows that the company can generate profits in 2017 and 2018. Audit quality has an average of 0.25, this shows that most of the companies audited are not from Big 4 Public Accounting Firm. Disclosure (corporate social responsibility) of $71.35 \%$, this shows that the company can pay for activities economic, social, and environmental development.
\end{abstract}

Keywords: Institutional Ownership, Company Performance, Extent of CSR Disclosure, Audit Quality 


\section{PENDAHULUAN}

Pengungkapan luas CSR yang dilakukan suatu perusahaan dapat meningkatkan nilai perusahaan tersebut, sebab teori Stakeholder menjelaskan bahwa perusahaan diwajibkan untuk mengungkapkan informasi kegiatan CSR yang dilakukan perusahaan sebagai suatu bentuk rasa tanggung jawab perusahaan terhadap stakeholder yang terkena dampak langsung maupun tidak langsung dari keberadaan perusahaan (Chariri, A., \& Ghozali, 2007). Tanggung jawab sosial perusahaan atau Corporate Social Responsibility (CSR) merupakan suatu gagasan yang menjadikan perusahaan tidak lagi dihadapkan pada tanggung jawab yang berpijak pada single bottom line, yaitu nilai perusahaan (corporate value) yang direfleksikan dalam kondisi keuangan (financial) saja (Nilasari, 2013).

Tanggung jawab perusahaan harus berpijak pada triple bottom lines yaitu kondisi keuangan, masalah sosial dan lingkungan. Suatu organisasi perusahaan memiliki suatu tanggung jawab yang besar terhadap pemegang saham, karyawan, konsumen, komunitas, dan lingkungan dalam aspek operasional perusahaan (Rimba, 2010). Permasalahan tentang Corporate Social Responsibility (CSR) di Indonesia diatur dalam Pasal 74 ayat 1 Undang-Undang No.40 Tahun 2007 tentang Perseroan Terbatas bahwa perseroan yang menjalankan kegiatan usahanya di bidang berkaitan dengan sumber daya alam wajib melaksanakan tanggung jawab sosial dan lingkungan, dan Undang-Undang Republik Indonesia Nomor 32 Tahun 2009 tentang Perlindungan dan Pengelolaan Lingkungan Hidup. Peraturan mengenai pengungkapan CSR diatur oleh Keputusan Ketua Badan Pengawas Modal dan Lembaga Keuangan (Bapepam-LK), kemudian pada tanggal 31 Desember 2012 sesuai dengan Undang Undang Republik Indonesia Nomor 21 tahun 2011 tugas pengawasan industri keuangan non-bank dan pasar modal secara resmi beralih dari Bapepam-LK ke Otoritas Jasa Keuangan (OJK). OJK menerbitkan Peraturan Otoritas Jasa Keuangan Nomor 51 Tahun 2017 mengenai CSR perusahaan publik wajib menerapkan keuangan berkelanjutan dalam kegiatan perusahaan publik (Pradnyana, K. D., \& Putra, 2018).

Adanya kepemilikan institusional akan mendorong peningkatan monitoring yang lebih maksimal. Semakin besar kepemilikan intitusional maka semakin efisien pemanfaatan aset perusahaan dan diharapkan juga bisa bertindak sebagai pencegahan terhadap pemborosan yang dilakukan oleh manajemen. Ketika pemanfaatan aset semakin baik maka kegiatan operasional perusahaan akan berjalan dengan lancar dan berdampak pada kenaikan laba perusahaan serta besarnya deviden yang dibagikan pada investor dan meningkatnya harga pasar saham perusahaan. Penelitian mengenai pengaruh kepemilikan institusional terhadap Corporate Social Responsibility (CSR) sudah banyak dilakukan, namun masih ada hasil empiris dari penelitian sebelumnya bervariasi ada yang menudukung dan ada pula yang tidak mendukung pengaruh dari kedua variabel tersebut. Menurut (Arum, Afrizal, 2011) terdapat pengaruh antara Kepemilikan Institusional terhadap pengungkapan Corporate Social Responsibility, selain itu (Dewi, 2018)memberikan penjelasan bahwa pengungkapan CSR sebagai variabel moderating, secara simultan dapat memoderasi pengaruh kepemilikan manajerial, kepemilikan institusional, komisaris independen, serta komite audit terhadap nilai perusahaan.

Pelaksanaan CSR bila alokasi sumberdaya perusahaan untuk kegiatan yang dilakukan untuk program CSR memberikan kontribusi bagi optimalisasi laba perusahaan yang sama dengan aktivitas alokasi sumberdaya perusahaan untuk kegiatan lainnya. Bila alokasi yang dilakukan perusahaan tidak mendatangkan kontribusi yang sebanding dengan alokasi sumberdaya untuk aktivitas lain yang bisa memberikan kontribusi untuk memaksimalkan laba perusahaan, maka hal ini manajer perusahaan telah melakukan tindakan yang bertentangan dengan kepentingan para pemegang saham (Solihin, 2009). Kenaikan laba merupakan salah satu indikator dari kinerja perusahaan. Banyak manfaat yang diperoleh perusahaan dengan pelaksanan corporate social responsibility serta mengungkapkannya. Jika dilihat dari perspektif ekonomi, suatu informasi akan diungkapkan perusahaan apabila dianggap dapat meningkatkan nilai perusahaan (Sayekti, Yosefa, Wondabio, 2007), dari sinilah pentingnya peningkatan kinerja perusahaan yang mampu 
meningkatkan nilai perusahaan melalui CSR. Pengungkapan CSR yang lebih luas akan meningkatkan kesadaran investor mengenai keberadaan perusahaan dan memperbesar basis investor, dan tentu saja mengurangi biaya modal. Di samping itu, kualitas yang lebih tinggi atau lebih spesifik dari pengungkapan tersebut akan mengurangi variasi dari arus kas sebuah perusahaan dengan arus kas dari perusahaan lain.

Nilai perusahaan meningkat karena kinerja perusahaan meningkat, menurut (Harmono, 2016) kinerja perusahan pada umumnya diukur berdasarkan penghasilan bersih (laba) atau sebagai dasar bagi ukur yang lain seperti imbalan investasi (return on investment) atau penghasilan per saham (Earning Per Share). Menurut (Sucipto, 2003) dalam Pujiasih mendefinisikan bahwa kinerja keuangan dalah penentuan ukuran-ukuran etertentu yang dapat mengukur keberhasilan suatu perusahaan dalam menghasilkan laba. Dalam penelitian ini, kinerja perusahaan diukur dengan menggunakan ROA. ROA berguna untuk mengukur sejauh mana efektivitas perusahaan dalam memanfaatkan seluruh sumber daya yang dimilikinya. Alasan menggunakan Return On Assets (ROA) karena dalam analisis manajemen keuangan mempunyai arti yang sangat penting sebagai salah satu teknik analisis keuangan yang bersifat menyeluruh atau komprehensif. Nilai ROA yang semakin besar menunjukkan kinerja perusahaan yang semakin baik.

Kualitas Audit memiliki fungsi untuk memastikan tujuan perusahaan tercapai, khususnya pada audit internal. kualitas audit dikatakan sebagai keadaan dimana seorang auditor akan menemukan dan melaporkan ketidaksesuaian terhadap prinsip yang terjadi pada laporan akuntansi. Salah satu pendekatan yang digunakan adalah pendekatan yang berorientasi hasil (outcome oriented) dan pendekatan yang berorientasi proses (process oriented) (Jones, G., 2013). Maraknya skandal keuangan yang terjadi baik di dalam maupun di luar negeri telah memberikan dampak besar terhadap kepercayaan publik terhadap profesi auditor dan yang menjadi pertanyaan besar dalam masyarakat adalah mengapa justru semua kasus tersebut melibatkan profesi auditor yang seharusnya sebagai pihak ketiga yang independen yang memberikan jaminan atas relevansi dan keandalan sebuah laporan keuangan. Kualitas audit didefinisikan sebagai kemungkinan (joint probability) bahwa auditor akan menemukan pelanggaran yang terjadi dalam sistem akuntansi dan melaporkannya dalam laporan keuangan auditan. Kualitas audit yang baik dapat dihasilkan jika auditor memiliki keahlian audit, integritas yang memadai untuk melakukan audit yang disertai dengan sikap bebas tidak memihak (independent) (Hasbullah, Erni Sulindawati, N. G., \& Herawati, 2014).

\section{TINJAUAN PUSTAKA \\ Kepemilikan Institusional}

Kepemilikan Institusional adalah kepemilikan saham perusahaan yang dimiliki oleh institusi. Adanya kepemilikan institusional dapat memantau secara profesional perkembangan investainya sehingga tingkat pengendalian terhadap manajemen sangat tinggi yang pada akhirnya dapat menekan potensi kecurangan (Agoes, 2011).

\section{Kinerja Perusahaan}

Pengukuran kinerja merupakan suatu proses penilaian tentang kemajuan pekerjaan terhadap tujuan dan sasaran dalam pengelolaan sumber daya manusia untuk menghasilkan barang dan jasa, termasuk informasi atas efisien serta efektivitas tindakan dalam mencapai tujuan organisasi. Kinerja adalah hasil kerja baik secara kualitas maupun kuantitas yang dicapai oleh seseorang (Moeheriono, 2012). Kinerja perusahaan umumnya diukur berdasarkan penghasilan bersih (laba) atau sebagai dasar bagi ukuran yang lain seperti imbalan investasi (return on investment) atau penghasilan per saham. Unsur yang berkaitan langsung dengan penghasilan bersih (laba) adalah penghasilan dan bebas (Harmono, 2016). 
Corporate Social Responsibility (CSR) merupakan usaha yang dilakukan oleh perusahaan dalam memberikan perhatian mereka pada lingkungan dan stakeholder pada umumnya. Pada umumnya CSR di berbagai negara dimaksudkan untuk memenuhi tujuan bisnis, yaitu guna memenuhi tujuan bisnis yaitu menghasilkan laba jangka panjang. Menggunakan kekuatan bisnis secara lebih bertanggungjawab, melakukan integrasi sicial demand dalam operasi bisnis, dan mendukung sesuatu yang bersifat sosial dan beretika (Kodrat, Sukardi, D., \& Indonanjaya, 2010).

\section{Kualitas Audit}

Kualitas audit menurut adalah suatu hasil yang telah dicapai oleh seorang subjek/objek untuk tingkat kepuasan, menjadikan akan memunculkan hasrat subjek/objek untuk menilai suatu kegiatan tersebut (Simanjuntak, 2008). Kualitas audit didefinisikan sebagai kemungkinan (joint probability) bahwa auditor akan menemukan pelanggaran yang terjadi dalam sistem akuntansi dan melaporkannya dalam laporan keuangan auditan (Hasbullah, Erni Sulindawati, N. G., \& Herawati, 2014).

\section{METODE PENELITIAN}

\section{Jenis Penelitian}

Jenis dari penelitian ini adalah penelitian asosiatif kausal. Penelitian ini meneliti hubungan yang bersifat sebab akibat. Penelitian ini termasuk ke dalam penelitian kuantitatif karena mengacu pada perhitungan berupa angka. Metode penelitian kuantitatif dapat diartikan sebagai metode penelitian yang berlandaskan pada filsafat positifisme, yang digunakan untuk meneliti populasi dan sampel tertentu, teknik pengambilan sampel biasanya dilakukan secara random, pengumpulam data menggunakan instrumen penelitian, analisis data bersifat kuantitatif/statistik yang memiliki tujuan untuk menguji hipotesis yang sudah ditetapkan. Peneliti kuantitatif dalam melihat hubungan variabel terhadap obyek yang diteliti lebih bersifat sebab akibat (kausal), sehingga dalam penelitiannya ada variabel independen dan dependen.

\section{Teknik Pengumpulan Data}

Penelitian ini dilakukan dengan pengambilan data di Bursa Efek Indonesia (BEI) melalui situs web www.idx.co.id dan Indonesian Capital Market Library (ICAMEL) melalui situs www.icamel.id Sumber data penelitian ini adalah data sekunder yang diperoleh secara historis dari laporan tahunan, laporan keuangan, dan laporan keberlanjutan yang disajikan perusahaan pada tahun 2017-2018 yang telah go public dan terdaftar di Bursa Efek Indonesia. Waktu pelaksanaan penelitian ini adalah dari bulan Januari 2020-Juni 2020. Populasi dalam penelitian ini adalah perusahaan tambang yang terdaftar di BEI sebanyak 43 perusahaan.

Sampel merupakan kumpulan bagian dari obyek yang diteliti. Dalam penelitian ini sampel yang diambil sesuai dengan kriteria yang digunakan dalam purposive sampling yang terdaftar selama tahun yang diteliti. Adapun kriteria tersebut adalah:

1. Perusahaan yang terdaftar di Bursa Efek Indonesia.

2. Perusahaan yang menerbitkan laporan tahunan pada tahun 2017-2018 dan laporan berkelanjutan pada tahun sebelumnya.

3. Perusahaan pertambangan yang listing di Bursa Efek Indonesia selama tahun 2017-2018.

4. Perusahaan yang memiliki kelengkapan data yang dibutuhkan dalam penelitian ini.

\section{Teknik Analisis Data}

Berdasarkan kriteria tersebut diperoleh jumlah sampel sebanyak 40 perusahaan.

Analisis data penelitian menggunakan model analisis regresi moderasi dikarenakan terdapat variabel pemoderasi dalam penelitian. 


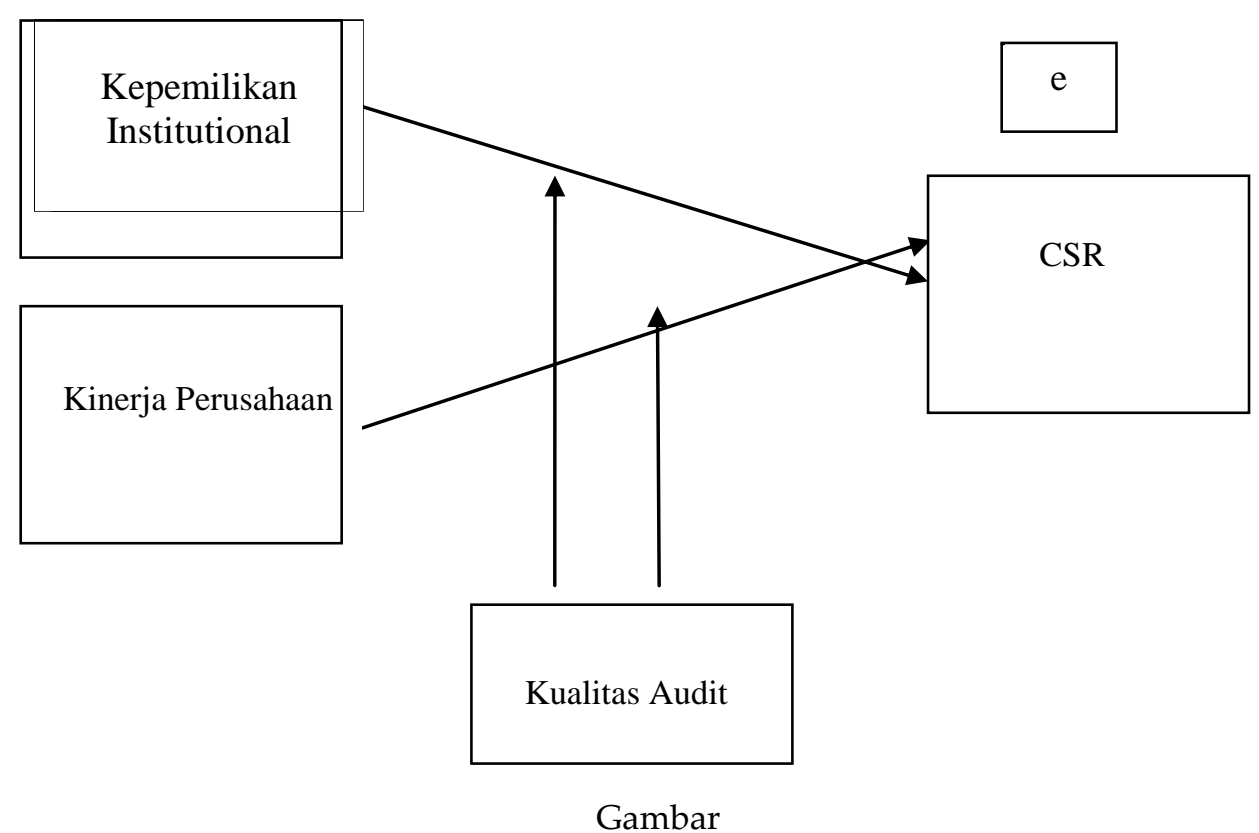

Pengaruh Kepemilikan Institusional dan Kinerja Perusahaan Terhadap CSR dimoderasi oleh Kualitas Audit

\section{PEMBAHASAN}

1. Deskripsi Kepemilikan Institusional, Kinerja Perusahaan, Kualitas Audit dan Luas Pengungkapan (Corporate Social Responsibility) CSR

Kepemilikan institusional merupakan sistem dan struktur yang baik untuk mengelola perusahaan dengan tujuan meningkatkan nilai pemegang saham serta mengakomodasikan berbagai pihak yang berkepentingan dengan perusahaan seperti, kreditur, supplier, asosiasi bisnis, konsumen, karyawan, pemerintah dan masyarakat luas. Hasil statistik deskriptif menunjukkan bahwa nilai rata-rata tata kepemilikan instistusional sebesar 55,92\%. Hal ini menunjukkan bahwa kepemilikan instisuional sudah cukup efektif dalam memonitor aktivitas manajemen.

Kinerja perusahaan perusahaan merupakan suatu gambaran tentang kondisi keuangan suatu perusahaan yang diproksikan dengan ROA, memiliki rata-rata sebesar 5,91\%. Hal ini menunjukkan bahwa perusahaan mampu menghasilkan keuntungan pada pada tahun 2017 dan 2018. Penilaian kinerja perusahaan merupakan salah satu cara yang dapat dilakukan oleh pihak manajemen agar dapat memenuhi kewajibannya terhadap para penyandang dana dan juga untuk mencapai tujuan yang telah ditetapkan oleh perusahaan. Kesalahan dalam pengelolaan kinerja perusahaan, akan berdampak pada rendahnya minat penyandang dana dalam berinvestasi.

Kualitas audit memiliki rata-rata sebesar 0,25, hal ini menunjukkan bahwa sebagian besar perusahaan diaudit bukan dari KAP Big 4 . Kualitas audit berperan penting karena audit yang berkualitas dapat menjaga kepercayaan, iklim investasi yang sehat dan transparansi ekonomi. Kualitas audit yang handal dapat mendorong pengambilan keputusan bagi pelaku usaha, pemerintah dan stakeholders lain.

Luas Pengungkapan (Corporate Social Responsibility) CSR merupakan suatu konsep yang lebih luas berkenaan dengan dampak dari aktivitas-aktivitas bisnis secara keseluruhan terhadap masyarakat. Hasil statistik deskriptif nilai rata-rata luas pengungkapan (corporate social resposibility) CSR sebesar $71,35 \%$, hal ini menunjukkan bahwa perusahaan mampu 
mengeluarkan biaya untuk kegiatan pembangunan ekonomi, sosial dan lingkungan. Perusahaan dapat menggunakan informasi CSR sebagai keunggulan kompetitif perusahaan. Perusahaan yang memiliki kinerja lingkungan dan sosial yang baik akan direspon positif oleh investor. Meningkatkan CSR membuat perusahaan menjadi lebih menarik bagi masyarakat dan investor.

2. Pengaruh Kepemilikan Institusional terhadap Luas Pengungkapan (Corporate Social Responsibility) CSR

Kepemilikan institusional berpengaruh terhadap luas pengungkapan (corporate social responsibility) CSR. Hal ini disebabkan kepemilikan institusional dipandang mempunyai kemampuan yang efektif dalam mengawasi aktivitas manajemen dan investor institusional bercenderungan berpihak pada manajemen dan lebih mendahulukan kepentingan investor institusional dibandingkan kepentingan pemilik, sehingga dapat menjadi sinyal positif bagi para investor untuk melakukan aksi beli saham yang berdampak pada peningkatan luas pengungkapan (corporate social responsibility) CSR. CSR dipandang sebagai perusahaan yang memiliki jiwa sosial tinggi, sehingga investor sebagai stakeholder akan lebih tertarik berinvestasi di perusahaan. Semakin banyak investor yang masuk tentu pendapatan atau income perusahaan akan semakin meningkat.

Kepemilikan institusional memiliki peranan yang sangat penting dalam meminimalisasi konflik keagenan yang terjadi antara manajer dan pemegang saham. Keberadaan investor institusional dianggap mampu menjadi mekanisme monitoring yang efektif dalam setiap keputusan yang diambil oleh manajer. Hal ini disebabkan investor institusional terlibat dalam pengambilan yang strategis perusahaan (Jensen, 1976). Semakin besar kepemilikan institusi maka akan semakin besar kekuatan suara dan dorongan dari institusi tersebut untuk mengawasi manajemen.

Kepemilikan institusional berperan sangat penting dalam meminimalisasi konflik keagenan yang terjadi antara pemegang saham dan manajer. Keberadaan investor institusional dianggap mampu menjadi mekanisme monitoring yang efektif dalam setiap keputusan yang diambil oleh manajer. Hasil penelitian ini mendukung (Edison, Emron, 2016) yang menyatakan bahwa kepemilikan saham institusional berperan dalam menentukan program CSR perusahaan dapat diimplementasikan. Namun tidak mendukung penelitian (Hapsoro, 2012) dan (jamil, erinos, 2019) yang menyatakan proporsi kepemilikan institusional tidak terbukti berpengaruh positif terhadap pengungkapan corporate social responsibility (CSR).

3. Pengaruh Kinerja Perusahaan terhadap Luas Pengungkapan (Corporate Social Responsibility) CSR

Kinerja perusahaan mempengaruhi luas pengungkapan (corporate social responsibility) CSR, yang berarti besar kecilnya kinerja perusahaan berdampak pada peningkatan CSR. Hal ini menunjukkan bahwa pelaksanaan kinerja perusahaan yang baik dapat meningkatkan luas pengungkapan (corporate social responsibility) CSR, dimana para investor cenderung menanamkan modal kepada perusahaan yang melakukan kegiatan CSR. Semakin tinggi nilai kinerja perusahaan maka akan direspon investor sehingga permintaan terhadap saham meningkat yang tercermin pada ROA mengalami peningkatan. Investor tertarik terhadap informasi sosial yang dilaporkan dalam laporan tahunan, sehingga manajemen perusahaan saat ini tidak hanya dituntut terbatas atas pengelolaan dana yang diberikan, namun juga meliputi dampak yang ditimbulkan oleh perusahaan terhadap lingkungan alam dan sosial. Return on Asset (ROA) yang positif menunjukkan bahwa modal yang diinvestasikan dalam keseluruhan aktiva yang dipergunakan untuk operasi perusahaan mampu memberikan laba bagi perusahaan, ROA yang negatif menunjukkan bahwa dari keseluruhan aktiva yang dipergunakan untuk operasi perusahaan tidak mampu memberikan keuntungan bagi perusahaan. 
Sebagai wujud nyata tanggung jawab sosial perusahaan atau CSR, perusahaan menyelenggarakan berbagai kegiatan. Kegiatan yang berhubungan dengan sosial antara lain: bantuan korban banjir, bantuan korban letusan gunung, kegiatan donor darah bekerja sama dengan PMI, dan bingkisan hari raya kepada masyarakat sekitar, serta program beasiswa yang yang berpotensi secara akademik, namun secara ekonomi kurang mampu untuk melanjutkan pendidikan. CSR di bidang kemitraan sarana dan pemberdayaan ekonomi masyarakat, sasaran kegiatan kemitraan adalah para pelaku usaha kecil dan menengah meliputi industri, peternakan, perikanan, perdagangan, jasa dan pertanian. Penelitian ini mendukung teori signaling yang menjelaskan bahwa manajer memberian sinyal positif melalui program CSR yang tinggi dengan tujuan untuk mengurangi asimetri informasi. Manajer memberikan informasi CSR yang lebih luas kepada sharehorder karena ingin memberikan ruang bagi investor untuk mengetahui bagaimana keputusan yang akan diambilnya berkaitan dengan nilai perusahaan tersebut, berdasarkan kinerja perusahaan yang diungkapkan dengan lebih transparan. Hasil penelitian ini konsisten dengan (Artha, 2014) yang menyatakan bahwa terdapat hubungan positif yang signifikan baik antara CSR dengan ROA maupun antara CSR dengan ROE.

4. Pengaruh Kualitas Audit terhadap Luas Pengungkapan (Corporate Social Responsibility) CSR

Kualitas audit berpengaruh terhadap luas pengungkapan (corporate social responsibility) CSR. Perusahaan menggunakan jasa auditor yang berkualitas dapat menjamin informasi laporan keuangan yang dilaporkan, sehingga pengguna laporan keuangan atau investor akan lebih percaya atas informasi yang disajikan. Semakin berkualitas auditor maka semakin tinggi kredibilitas angka akuntansi yang dilaporkan, dengan demikian semakin besar tingkat pengungkapan luas pengungkapan (corporate social responsibility) CSR. CSR merupakan faktor penting keberlangsungan hidup dari suatu perusahaan dan sebagai bentuk tanggung jawab sebuah perusahaan terhadap semua pemegang kepentingan. Oleh karena itu suatu perusahaan membutuhkan dukungan para pemegang kepentingan untuk menjalankan operasional perusahaan. Dalam jangka panjang, CSR akan menjadi suatu aset strategis dan kompetitif bagi korporasi ditengah iklim bisnis yang menuntut praktik-praktik bisnis yang etis dan bertanggung jawab. Hasil penelitian ini mendukung (Hapsoro, 2012) kualitas audit terbukti berpengaruh positif terhadap pengungkapan corporate social responsibility (CSR)

5. Kualitas Audit Dalam Memoderasi Pengaruh Kepemilikan Institusional dan Kinerja Perusahaan Terhadap Luas Pengungkapan (Corporate Social Responsibility) CSR

Kualitas audit memperkuat pengaruh kepemilikan institusional dan kinerja terhadap luas pengungkapan (corporate social responsibility) CSR. Kualitas audit merupakan segala kemungkinan dimana auditor pada saat mengaudit laporan keuangan klien dapat menemukan pelanggaran yang terjadi dalam sistem akuntansi klien dan melaporkannya dalam laporan keuangan auditan, dimana dalam melaksanakan tugasnya tersebut auditor berpedoman pada standar auditing dan kode etik akuntan publik yang relevan. Kantor Akuntan Publik (KAP) sebagai salah satu perusahaan yang bergerak dalam bidang jasa, harus dapat memberikan jasa yang berkualitas guna dapat memenuhi kebutuhan pemegang saham. Profesi akuntan publik bertanggungjawab untuk menaikkan tingkat keandalan laporan keuangan perusahaan, sehingga masyarakat memperoleh informasi keuangan yang andal sebagai dasar pengambilan keputusan.

KAP big four diyakini akan memberikan jasa audit yang lebih independen dan transparan dalam mengungkapkan misstatement yang disajikan dalam laporan keuangan perusahaan. KAP big four akan mempertahankan reputasinya sebagai perusahaan terbaik yang akan memberikan jasa yang berkualitas dengan tetap mempertahankan prinsip-prinsip dan standar akuntansi serta kode etik yang dimiliki (Lennox, 2002). Kualitas audit selain ditentukan oleh faktor tim audit juga ditentukan oleh pengalaman teknis dan pengalaman dalam industri, 
respon terhadap kebutuhan klien, dan kemampuan berkomunikasi dengan klien. Menurut (Hartana, I. B. P. R., \& Putra, 2017) Corporate Social Responsibility sebagai variabel pemoderasi mampu memoderasi pengaruh kepemilikan manajerial terhadap nilai perusahaan tetapi tidak mampu memoderasi pengaruh kepemilikan institusional terhadap nilai perusahaan. Kepemilikan institusional yang terdiri dari perusahaan perbankan, asuransi, dan dana pensiun di Indonesia belum mempertimbangkan CSR sebagai salah satu kriteria dalam melakukan investasi, sehingga para investor institusional cenderung tidak menekan perusahaan untuk mengungkapan CSR secara rinci dalam laporan tahunan perusahaan.

\section{KESIMPULAN}

Hasil statistik deskriptif menunjukkan bahwa nilai rata-rata tata kepemilikan instistusional sebesar 55,92\%. Hal ini menunjukkan bahwa kepemilikan instisuional sudah cukup efektif dalam memonitor aktivitas manajemen. Kinerja perusahaan perusahaan merupakan suatu gambaran tentang kondisi keuangan suatu perusahaan yang diproksikan dengan ROA, memiliki rata-rata sebesar $5,91 \%$. Hal ini menunjukkan bahwa perusahaan mampu menghasilkan keuntungan pada pada tahun 2017 dan 2018.

Kualitas audit memiliki rata-rata sebesar 0,25 , hal ini menunjukkan bahwa sebagian besar perusahaan diaudit bukan dari KAP Big 4. Hasil statistik deskriptif nilai rata-rata luas pengungkapan (corporate social resposibility) CSR sebesar 71,35\%, hal ini menunjukkan bahwa perusahaan mampu mengeluarkan biaya untuk kegiatan pembangunan ekonomi, sosial dan lingkungan.

Kepemilikan institusional berpengaruh terhadap luas pengungkapan (corporate social responsibility) CSR. Hal ini disebabkan kepemilikan institusional dipandang mempunyai kemampuan yang efektif dalam mengawasi aktivitas manajemen dan investor institusional bercenderungan berpihak pada manajemen dan lebih mendahulukan kepentingan investor institusional dibandingkan kepentingan pemilik, sehingga dapat menjadi sinyal positif bagi para investor untuk melakukan aksi beli saham yang berdampak pada peningkatan luas pengungkapan (corporate social responsibility) CSR.

Kinerja perusahaan mempengaruhi luas pengungkapan (corporate social responsibility) CSR, yang berarti besar kecilnya kinerja perusahaan berdampak pada peningkatan CSR. Hal ini menunjukkan bahwa pelaksanaan kinerja perusahaan yang baik dapat meningkatkan luas pengungkapan (corporate social responsibility) CSR, Kualitas audit berpengaruh terhadap luas pengungkapan (corporate social responsibility) CSR. Kualitas audit memperkuat pengaruh kepemilikan institusional dan kinerja terhadap luas pengungkapan (corporate social responsibility) CSR. Kualitas audit merupakan segala kemungkinan dimana auditor pada saat mengaudit laporan keuangan klien dapat menemukan pelanggaran yang terjadi dalam sistem akuntansi klien dan melaporkannya dalam laporan keuangan auditan, dimana dalam melaksanakan tugasnya tersebut auditor berpedoman pada standar auditing dan kode etik akuntan publik yang relevan.

\section{DAFTAR PUSTAKA}

Agoes, \& S. (2011) Etika Bisnis dan Profesi. Jakarta: Salemba Empat.

Artha, H. dan D. (2014) 'Pengaruh Keahlian Audit, Konflik Peran dan Kompleksitas Tugas terhadap Audit Judgment (Studi Kasus pada Inspektorat Pemerintah Kabupaten Gianyar dan Kabupaten Bangli)', 2 Nomor 1.

Arum, Afrizal, \& R. (2011) Pengaruh Kepemilikan Manajemen serta Kepemilikan Institusional, 
Profitabilitas dan Kinerja LIngkungan (Enviromental Performance) terhadap Pengungkapan Corporate Social Responsibility (Studi Empiris Perusahaan Pertambangan Periode 2015-2017. Tesis Universitas Jambi.

Chariri, A., \& Ghozali, I. (2007) Teori Akuntansi. Semarang: Badan Penerbit Universitas Diponegoro.

Edison, Emron, D. (2016) Manajemen Sumber Daya Manusia. 1st edn. Bandung: Alfabeta.

Hapsoro, D. (2012) 'Pengaruh corporate governance dan kualitas audit terhadap pengungkapan corporate social responsibility', Jurnal Akuntansi dan Manajemen.

Harmono (2016) Manajemen Keuangan: Berbasis Balanced Scorecard Pendekatan Teori, Kasus, dan Riset Bisnis. Jakarta: Bumi Aksara.

Hartana, I. B. P. R., \& Putra, N. W. A. (2017) 'Pengaruh Kepemilikan Manajerial dan Kepemilikan Institusional Pada Nilai Perusahaan Dengan Corporate Social Responsibility Sebagai Pemoderasi', E-Jurnal Akuntansi Universitas Udayana, 21(3), pp. 1903-1932.

Hasbullah, Erni Sulindawati, N. G., \& Herawati, N. T. (2014) ‘Pengaruh keahlian audit, kompleksitas tugas, dan etika profesi terhadap kualitas audit. Penelitian ini dilaksanakan di Inspektorat Pemerintah Kota Denpasar dan Inspektorat Pemerintah Kabupaten Gianyar', Jurnal Akuntansi, pp. 1-14.

jamil, erinos, \& afriyanti (2019) 'Pengaruh kepemilikan institutional terhadap nilai perusahaan dengan CSR sebagai variabel moderasi studi empiris pada perusahaan property dan real estate tahun 2015-2017', Jurnal Eksplorasi Akuntansi.

Jensen, \& M. (1976) 'The Teory of The Firm: Manajerial Behaviour, Agency Cost, and Ownership Structure', Journal of Financial and Economics.

Jones, G., \& B. (2013) ‘Local Council Governance and Audit Committees The Missing Link', Journal of New Business Ideas and Trends, pp. 58-66.

Kodrat, Sukardi, D., \& Indonanjaya, K. (2010) Manajemen Investasi. Yogyakarta: Ghalia Ilmu.

Lennox, C. (2002) Opinion Shopping and Audit Committees. Available at: www.google.com.

Moeheriono (2012) Pengukuran Kinerja Berbasis Kompetensi. Jakarta: Raja Grafindo Persada.

Nilasari (2013) ‘Pengaruh Profitabilitas, Kepemilikan Institusional, Kepemilikan Asing, dan Size terhadap CSR Disclosure Perusahaan Tambang (Mining Sector) yang melakukan Listing di Bursa Efek Indonesia', Akuntansi, pp. 1-20.

Pradnyana, K. D., \& Putra, I. P. (2018) ‘Moderasi Corporate Social Responsibility Pada Pengaruh Profitabilitas Terhadap Nilai Perusahaan Pada Perusahaan Manufaktur', E-Jurnal Akuntansi, 24 nomor 1.

Rimba, K. (2010) Pengaruh Corporate Social Responsibility terhadap Nilai Perusahaan dengan Profitabilitas sebagai Variabel Moderating. Universitas Diponegoro. 
Sayekti, Yosefa, Wondabio, \& L. (2007) Pengaruh CSR Disclosure Terhadap Earning Response Coefficient: Suatu Studi Empiris Pada Perusahaan yang Terdaftar Di Bursa Efek Jakarta. Jakarta.

Simanjuntak, \& P. (2008) Pengaruh Time Budget Pressure dan Resiko Kesalahan. Universitas Diponegoro.

Solihin, \& I. (2009) Corporate Social Responsibility from Charity to Sustainability. Jakarta: Salemba Empat.

Sucipto (2003) ‘Penilaian Kinerja Keuangan’, Jurnal akuntansi. 